\title{
IMPORTANCE-PERFORMANCE ANALYSIS TO ARJOSARI TERMINAL
}

\author{
SEDAYU, Agung \\ Department of Architecture, State Islamic University of Maulana Malik Ibrahim Malang \\ Jalan Gajayana 50, Malang, East Java, Phone +62341 558933 \\ Email: agung_resta@yahoo.co.id
}

\begin{abstract}
Public transport is one of the important solutions to solve transportation problems in Indonesia. At this present, the level of congestion and traffic accidents were very high. This was caused by increasing in using cars and motorcycles. This condition is not matched by public transport services that are decreasing in quantity and performance quality of the vehicles. Therefore with the issues it needs improve public transport services that are reliable and cheap. This study suggests efforts to improve public transport services based terminal user perceptions. This study location is Arjosari terminal. The method is Importance-Performance Analysis (IPA). The analysis results obtained service attributes include assurance, responsiveness, performance, aesthetics, easy, reliability, durability, frequency, comfort, and the availability of facilities. The results get priority to be repaired include security protection and safety, Aesthetics waiting room, no long in waiting time, provide information and complaint center, and the available of Goods repository.
\end{abstract}

Keywords: Importance; performance; service attributes; public transport terminal.

\section{INTRODUCTION}

Transport problems in Indonesia at this time more complicated and complex. Those problems include traffic jams, highly traffic accidents, environmental pollution due to vehicle pollution, and issue of transport infrastructure services. Public transport as one of the solutions to solve transporttation problems in Indonesia has been decreased in its performance. This caused many users like private vehicles rather than using public transport. The transport data of Surabaya City which is one of the major cities in Indonesia and the capital of East Java Province, Indonesia, rised to $455 \%$ in using personal vehicles from 1976 to 1998 (Sulistio and Silitonga, 2010). Public transport declining in quantity and service caused terminal performance and service degradation. Terminal as nodes to change modes of public transport have important role in solving transportation problems (Rauf, 2002). The performance declining of terminal as one of the transport infrastructure is not only caused by the decline in public transport. There are several factors that contribute to determine the problem includes the availability of facilities, location, minimum requirements, easy and amenities in the terminal. This study seeks to obtain the factors that influence public transport terminal services according to level of user importance and satisfaction. This study to analyses the factors according to user importance and satisfaction by using importance classification diagram. From the diagram could be obtained the improvement priorities of services quality. Users include passengers who regularly (often) and rarely use the terminal. The research location is Arjosari terminal in Malang City, East Java Province, Indonesia. Arjosari terminal as the main terminal type A is located in Malang city which has a very important role in linking public transport modes from the northern, eastern and western part of East Java. Malang as the second biggest city in East Java after Surabaya has a strategic position as transit node. The method that used is the Importance-Performance Analysis (IPA) to service attributes of public transport terminals. Survey steps consisted of a preliminary and continuation survey. Both surveys were conducted by interview and filling questionnaire by the user terminal.

\section{LITERATURE REVIEWS}

\section{Concept Framework of Terminal Performance Determination}

Concept Framework of terminal performance and services determination as public facilities based on the concept of Performance Based Design of Buildings (PeBBu) (Spekkink, 2005). The Performance Based Design of Buildings (PeBBu) provide understanding and performance-based development by considering the similarity between the terminal technical aspects with user needs called voice of user. This research stages carried out by 
preliminary survey to respondents and scoring the level of service attributes need of public transport terminal. Preliminary surveys consist of observation to terminal existing conditions and distribute questionnaires to terminal user as respondents. Service attributes as a research variable is based on the attributes of the terminal regulations in Indonesia, study and previous research, and attributes according to user needs. From the scoring process can be obtained requirements level rating of service attributes. The scoring use SPSS 19 which one program to analyze statistic descriptive. Furthermore, the scoring results are used to determine a standard service attributes are arranged in questionnaires that are ready to be distributed to respondents (users) through continuation survey. The continuation survey was conducted to determine the level of user importance and satisfaction for a standard service attributes by using importance-performance analysis (IPA). The method that is developed in this study is shown in Figure 1.

\section{Terminal Classification}

The terminal of this research is the terminal type A as regulation of Transportation Minister Number 31 year of 1995 which provide the definition and classification of the terminal in Indonesia as follows:

a. Type A, has function to serve public transport for inter-city and inter-provincial transportation, state boundary transportation, transportation between cities in the province, and urban and rural transportation;

b. Type B, has function to serve public transport for transportation between cities in the province, and urban and rural transportation;

c. Type $\mathrm{C}$, has function to serve public transport for rural transportation.

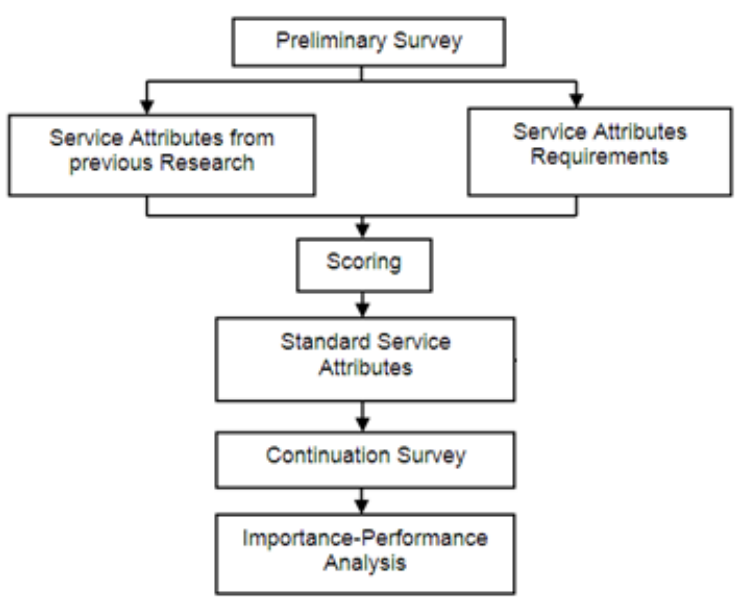

Figure 1. Research Method Development

\section{Research Sampling Determination}

Respondents who have been targeted in information collecting of service attributes needs are passenger who regularly (often) and rarely use the terminal. Number of respondent are taken by use minimal sample at least 30 people (Sugiyono, 2009). To avoid fault data, this research use 45 peoples to become respondents. Number of respondents for continuation survey is determined by stratified random sample technique, it will obtain terminal users stratum. Research samples that were targeted in this study are the terminal users that are public transport passengers. Determination of minimum sample can be sought by the Bernoulli equation:

$N \geq \frac{\left(z_{a / 2}\right)^{2} p \cdot q}{e^{2}}$

so that become

$N \geq \frac{(1,96)^{2} \cdot 0,95 \cdot 0,05}{(0,05)^{2}} \rightarrow \mathrm{N} \geq 72,99 \approx 73$

Where:

$\mathrm{N}=$ number of minimum samples

$\mathrm{Z}=$ the value of the normal distribution

$\mathrm{e}=$ error

$\mathrm{p}=$ proportion of questionnaires that are assumed true

$\mathrm{q}=$ proportion of questionnaires that are assumed wrong

Value is assumed correct by $95 \%$, then the number of questionnaires that are assumed wrong is $5 \%$. To avoid lacking of data because of mistake of filling or the questionnaires are not return, the number of respondents to be used by 150 peoples with the details:

- Passengers who regularly or often use the terminal and its facilities $=75$ peoples

- Passengers who rarely use the terminal and its facilities $=75$ peoples

\section{Services Attribute Determination}

The service attributes are refers to previous researches that are described in Table 1. The service attributes are matched to the existing condition and location of the terminal, then prepared a questionnaire to be filled by public transport passengers in the preliminary survey.

Questionnaire is form of question items contain terminal service attributes that are measured with a Likert scale (see Table 2). 
Table 1. Variables from Previous Research

\begin{tabular}{|c|c|c|c|}
\hline No & Researcher & Year & Services Attributes \\
\hline 1 & Dragu & 2001 & $\begin{array}{l}\text { Security, reliability, frequency, accessibility, commercial areas, information, } \\
\text { comfort, and aesthetic }\end{array}$ \\
\hline 2 & Ockwell & 2001 & Time and convenience \\
\hline 3 & Rauf & 2002 & Availability and condition of facilities, comfort, and safety \\
\hline 4 & Kido & 2005 & Aesthetics \\
\hline 5 & Sholichin & 2005 & Space and land area \\
\hline 6 & Harsanto & 2007 & Reliability, responsiveness, assurance, and physical appearance \\
\hline 7 & Rini & 2007 & $\begin{array}{l}\text { Security/safety, facilities, personnel and operator services, carriers, parking, } \\
\text { ticketing, bus transportation service, cleanliness and comfort, pedestrian facilities, } \\
\text { bus stops, and accessibility }\end{array}$ \\
\hline 8 & Ismail & 2008 & Accessibility, mistakes and violations of public transport \\
\hline 9 & Marliana \& Dharmastiti & 2008 & $\begin{array}{l}\text { employees ability, comfort, punctuality, number of shelters, the number of bus } \\
\text { lines, bus density, and disabled facilities }\end{array}$ \\
\hline 10 & Purba & 2009 & $\begin{array}{l}\text { Facilities and management, accessibility, level of service of road, safety and } \\
\text { environmental comfort }\end{array}$ \\
\hline 11 & Weningtyas & 2009 & Reliability, physical aspects, and responsiveness. \\
\hline 12 & Pati & 2009 & $\begin{array}{l}\text { Time, ticket payment flexibility, safety of passengers and goods, and easy on } \\
\text { telecommunication services }\end{array}$ \\
\hline 13 & Jarsemskiene & 2009 & Time, efficiency, cost, responsiveness, and accessibility \\
\hline 14 & Chen & 2009 & Safety and security \\
\hline 15 & Lutfi & 2009 & Security, comfort, distance, and travel time. \\
\hline 16 & Nurfanti & 2009 & Reliability, responsiveness, assurance, and empathy. \\
\hline 17 & LHB-LSA Design & 2009 & Connectivity, availability of facilities, and aesthetics \\
\hline 18 & Saputra & 2010 & $\begin{array}{l}\text { Arrival and departure times, information systems for services, regularity of luggage } \\
\text { workers and brokers, road conditions, and terminal facilities }\end{array}$ \\
\hline
\end{tabular}

Table 2. Likert Scale of Measurement

\begin{tabular}{ccc}
\hline Score & Importance & Satisfaction \\
\hline 1 & Not important & Not satisfactory \\
2 & Less important & Less satisfactory \\
3 & Quite important & Quite satisfactory \\
4 & Important & Satisfactory \\
5 & Very important & Very satisfactory \\
\hline
\end{tabular}

\section{Validity and Reliability Test}

Validity test was conducted to determine the validity of the questionnaire that will be distributed to respondents. The test carried out on 30 people (Sugiyono, 2009). For the validity test, we use Pearson product moment correlation that is formula to calculate the correlation coefficients of each item with the total score. The formula is;

$r_{x y}=\frac{N \sum X Y-\left(\sum X\right)\left(\sum Y\right)}{\sqrt{\left.\left[\left\{N \sum X^{2}-\left(\sum X\right)^{2}\right\}\left(N \sum Y^{2}\right)-\left(\sum Y\right)^{2}\right\}\right]}}$

Where:

$\mathrm{r}_{\mathrm{xy}}=$ correlation coefficient of searched items

$\mathrm{X}=$ respondents score for each item

$\mathrm{Y}=$ respondent total score of all items

$\Sigma X=$ sum of scores in the distribution $X$

$\Sigma \mathrm{Y}=$ sum of scores in the distribution $\mathrm{Y}$

$\Sigma X^{2}=$ sum of squares of each score $X$
$\Sigma \mathrm{Y}^{2}=$ sum of squares of each score $\mathrm{Y}$

$\mathrm{N}=$ number of subjects

Reliability test was conducted to determine whether the data collection tool shows the level of precision, accuracy, stability, or consistency in expressing certain symptoms of a group of individuals, even if done at different times. Reliability test conducted on items that have been strongly correlated. For Internal Consistency test using consistency coefficient (Cronbach's alpha). Cronbach's Alpha equation used in this reliability test is: $r_{1}=\left[\begin{array}{l}k \\ k-1\end{array}\right]\left[\begin{array}{l}1-\sum \sigma b^{2} \\ \sigma \cdot t^{2}\end{array}\right]$

Where:

$\mathrm{r}_{1} \quad=$ instruments consistency

$\mathrm{k}=$ number of questions items

$\Sigma \sigma b^{2}=$ number of items variance

$\sigma \mathrm{b}^{2}=$ total variance

In this study, an instrument said to be strongly correlated if the correlation value above of 0.6 (Sugiyono, 2009). The instrument is reliable if the value of alpha coefficient (Cronbach's alpha coefficient) is above of 0.60 (Sugiyono, 2009). Validity and reliability test of the questionnaire with SPSS 19. 


\section{User Importance Performance Analysis (IPA)}

This analysis is intended to get user importance to service attributes. In principle, IPA combines dimensional measurements to the expectations and importance two grids (see IPA diagram in Figure 2), then both dimensions were plotted into it. Importance value is plotted as the vertical axis while the expected value as a diagonal axis by using the mean value contained in importance and expectation dimension as the center line cutting. The diagram consists of fourquadrant that shows level of importance to service attributes. IPA is used to get the importance of customer to service attributes. The level of importance is described in the importance diagram that is divided into four quadrants (Figure 2) with description as follows,

a. Quadrant A, the area that contains the attributes are considered important by customers but not as expected (levels of customer satisfaction are still very low). In this area the management institution perform improvements continuously in order to increase performance in this quadrant.

b. Quadrant B, the area that contains the attributes is considered important by customers and the attributes are assumed in accordance with the perceived so the level of satisfaction is high.

c. Quadrant C, the area that is contains attributes are considered less important by the customer and in fact have less special performance.

d. Quadrant D, the area that contains the attributes are considered less important by the customer and assumed excessive.

In the user importance and satisfaction collecting, the survey result can be compared. Table 3 shows the data between terminal user satisfaction and importance.

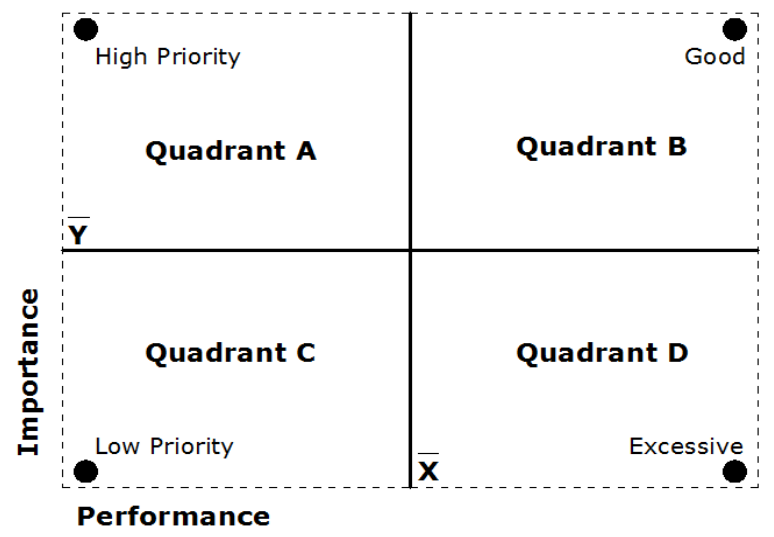

Source: Wijaya, 2011

Figure 2. Importance Classification Diagram

\section{RESULTS AND DISCUSSIONS}

\section{Preliminary Survey Results}

Observation and documentation stages for secondary data from the management institution of Arjosari terminal obtain results as in Table 4.

From previous studies and surveys about service attributes needs in Arjosari terminal, then determine ten basic services attributes of Arjosari terminal Malang. The survey results can be seen in Table 5 .

Ten attributes compiled in Table 5 in the list of questionnaires which distributed to respondents through preliminary surveys. Scoring in questionnaire is analyzed by using SPSS 19 and the results are summarized in Table 6. From Table 6 it can be seen that the highest service attributes are availability of terminal facilities $\left(\mathrm{A}_{10}\right)$ with a total score of 184 and a mean value of 4.09 , while the lowest is Durability of public transport services and facilities with a total score of 156 and a mean value of 3.47. This suggests that the availability of terminal facilities in Arjosari terminal is very important to be improved.

Availability of terminal facilities $\left(\mathrm{A}_{10}\right)$ is described into 21 criteria that the facilities should be improved by the terminal management institution. Preliminary survey result can be calculated levels of user needs to 21 terminal facilities where the highest total score is the waiting room (F-3) with a total score of 186 (mean value 4.133), while the lowest is mosque (F14) with a total score of 159 and the mean value of 3.533. More results can be seen in Table 7 .

The Ten basic attributes in Table 5 is described into 54 detailed terminal service attributes in order to be more valid measurements. Fifty-four attributes arranged in questionnaire that is prepared to distribute to the respondents through continuation survey. The continuation survey results can be seen in Table 8 .

Table 3. Data between Satisfaction and Importance

\begin{tabular}{cccc}
\hline No & Service Attributes & Satisfaction & Importance \\
\hline 1 & Attribute 1 & Score $x_{1}$ & Score $y_{1}$ \\
2 & Attribute 2 & Score $x_{2}$ & Score $y_{2}$ \\
3 & Attribute 3 & Score $x_{3}$ & Score $y_{3}$ \\
4 & Attribute 4-and so on & Score $x_{4}$ & Score $y_{4}$ \\
\hline
\end{tabular}

Table 4. Existing Data of Arjosari Terminal

\begin{tabular}{rlc}
\hline No & Criteria & Definiton \\
\hline 1 & City & Malang \\
2 & Management institution & Transportation agency \\
3 & Land area & $60030 \mathrm{~m} 2$ \\
4 & First time to operate & 1989 \\
5 & The number of bus passengers & 1347102 people \\
& in 2011 & \\
6 & The number of bus in 2011 & 92276 bus \\
\hline
\end{tabular}


Table 5. Classification of Basic Service Attributes

\begin{tabular}{clc}
\hline No & \multicolumn{1}{c}{ Service Attributes } & Notation \\
\hline 1 & Assurance in Security, safety, health, and availability of transport modes & $\mathrm{A}_{1}$ \\
2 & Staff responsiveness in provision of care, responsiveness to problems, polite and friendly, and have good & $\mathrm{A}_{2}$ \\
& skills & \\
3 & $\begin{array}{l}\text { Terminal facilities Performance include lighting, air circulation, parking lots, roads, waiting room, small } \\
\text { mosque, stalls, kiosks, hall, corridors, toilet, sculpture, and waste management }\end{array}$ & $\mathrm{A}_{3}$ \\
4 & Facilities aesthetics include waiting rooms, corridors, arrival and departure gate, parks, and landscaping & $\mathrm{A}_{4}$ \\
5 & Amenity and Easy accessibility in location, circulation, tickets, prices, information, facilities, and no & $\mathrm{A}_{5}$ \\
& additional cost (extortion) & $\mathrm{A}_{6}$ \\
6 & Reliability in arrivals and departures, waiting time, and public transportation ticketing service & $\mathrm{A}_{7}$ \\
7 & Durability of public transport services and facilities & $\mathrm{A}_{8}$ \\
8 & Frequency in passenger queues, overcrowding, and the level of traffic congestion & $\mathrm{A}_{9}$ \\
9 & Convenience and comfort from cigarette smoke, fumes, odors, noise, glare, view, brokers, and gain & \\
& terminal cleanliness and regularity & $\mathrm{A}_{10}$ \\
10 & Availability of terminal facilities & \\
\hline
\end{tabular}

Table 6. Statistical Description of a Preliminary Survey Results in Terminal Arjosari

\begin{tabular}{lcccccccccc}
\hline \multirow{2}{*}{ Description } & \multicolumn{10}{c}{ Service Attributes of Arjosari terminal Malang } \\
\cline { 2 - 11 } & A1 & A2 & A3 & A4 & A5 & A6 & A7 & A8 & A9 & A10 \\
\hline 1. Respondent & 45 & 45 & 45 & 45 & 45 & 45 & 45 & 45 & 45 & 45 \\
2. Mean & 3.93 & 3.60 & 3.64 & 3.67 & 3.73 & 3.98 & 3.47 & 3.56 & 3.80 & 4.09 \\
3. Median & 3.94 & 3.60 & 3.61 & 3.60 & 3.71 & 4.03 & 3.45 & 3.52 & 3.81 & 4.11 \\
4. Mode & 4 & 4 & 3 & 3 & 3 & 4 & 3 & 3 & 4 & 4 \\
5. Std. Deviation & 0.78 & 0.84 & 0.93 & 0.95 & 0.91 & 0.87 & 0.89 & 0.94 & 0.87 & 0.73 \\
6. Variance & 0.61 & 0.70 & 0.87 & 0.91 & 0.84 & 0.75 & 0.80 & 0.89 & 0.5 & 0.54 \\
7. Range & 3 & 3 & 3 & 3 & 3 & 3 & 3 & 3 & 3 & 2 \\
8. Minimum Score & 2 & 2 & 2 & 2 & 2 & 2 & 2 & 2 & 2 & 3 \\
9. Maximum Score & 5 & 5 & 5 & 5 & 5 & 5 & 5 & 5 & 5 & 5 \\
10. Total Score & 177 & 162 & 164 & 165 & 168 & 179 & 156 & 160 & 171 & 184 \\
\hline
\end{tabular}

Table 7. The Level of Requirement and Availability Rank of Terminal Facilities

\begin{tabular}{|c|c|c|c|c|}
\hline \multirow{2}{*}{ No } & \multirow{2}{*}{ Terminal Facilities } & \multirow{2}{*}{ Notation } & \multicolumn{2}{|c|}{ Score } \\
\hline & & & Total & Mean value \\
\hline 1 & Parking area for bicycle and motorcycle & F-1 & 169 & 3.756 \\
\hline 2 & Parking area for car & $\mathrm{F}-2$ & 174 & 3.867 \\
\hline 3 & Waiting room & F-3 & 186 & 4.133 \\
\hline 4 & Kiosks and retail & F-4 & 176 & 3.911 \\
\hline 5 & Waste management facilities & F-5 & 166 & 3.689 \\
\hline 6 & Rest area and lodging facilities & F-6 & 180 & 4.000 \\
\hline 7 & Canteens, restaurants and food shops & F-7 & 169 & 3.756 \\
\hline 8 & Travel information boards & F-8 & 163 & 3.622 \\
\hline 9 & Information and complaints center & F-9 & 181 & 4.022 \\
\hline 10 & Goods repository & F-10 & 175 & 3.889 \\
\hline 11 & Tariffs board per route & F-11 & 176 & 3.911 \\
\hline 12 & Toilet & F-12 & 171 & 3.800 \\
\hline 13 & Religious facilities : place for pray & F-13 & 171 & 3.800 \\
\hline 14 & Religious facilities : mosque & F-14 & 159 & 3.533 \\
\hline 15 & Signs transportation routes & F-15 & 173 & 3.844 \\
\hline 16 & Telecommunication facilities (telephone,internet,TV) & F-16 & 176 & 3.911 \\
\hline 17 & Travel agent counters & F-17 & 176 & 3.911 \\
\hline 18 & Health aid center & F-18 & 181 & 4.022 \\
\hline 19 & Bank & F-19 & 175 & 3.889 \\
\hline 20 & ATM center & $\mathrm{F}-20$ & 180 & 4.000 \\
\hline 21 & Money changer & $\mathrm{F}-21$ & 161 & 3.578 \\
\hline
\end{tabular}


Table 8. The Mean Values of Level of Importance and Level of Satisfaction in Arjosari Terminal

\begin{tabular}{|c|c|c|c|}
\hline \multirow[t]{2}{*}{ No } & \multirow[t]{2}{*}{ Service Attributes } & \multicolumn{2}{|c|}{$\begin{array}{c}\text { Mean Values } \\
\text { Nilai Rata-Rata (mean) }\end{array}$} \\
\hline & & Satisfaction & Importance \\
\hline 1 & Security and safety protection & 3.927 & 3.933 \\
\hline 2 & Providing health help and aid & 3.927 & 3.807 \\
\hline 3 & Obtaining necessary transport modes & 4.220 & 4.060 \\
\hline 4 & Clarity assurance in travel destinations selection & 4.027 & 3.927 \\
\hline 5 & Employees attention to all customer complaints & 4.020 & 3.827 \\
\hline 6 & Employees responsive to all customer problems & 4.060 & 3.920 \\
\hline 7 & Employees serving with polite, friendly, and neat & 4.093 & 3.907 \\
\hline 8 & Employees have sufficient skills and abilities & 4.087 & 3.707 \\
\hline 9 & Functioning of lighting (natural and artificial) & 3.967 & 3.793 \\
\hline 10 & Functioning of bathroom facilities & 3.993 & 3.853 \\
\hline 11 & Functioning of air circulation & 3.813 & 3.787 \\
\hline 12 & Good road performance & 3.887 & 3.760 \\
\hline 13 & Good parking performance & 4.040 & 3.873 \\
\hline 14 & Waiting room aesthetically & 3.887 & 3.833 \\
\hline 15 & Corridor aesthetically & 4.020 & 3.887 \\
\hline 16 & Arrival and departure gate aesthetically & 3.933 & 3.673 \\
\hline 17 & Garden and landscape aesthetically & 4.020 & 4.013 \\
\hline 18 & Amenity and easy accessibility in location & 4.007 & 3.860 \\
\hline 19 & Amenity and easy in room or space circulation & 3.973 & 3.913 \\
\hline 20 & Easy for getting ticket & 3.967 & 3.813 \\
\hline 21 & Reaching prices such as ticket, taxes, food, and drinks & 3.813 & 3.707 \\
\hline 22 & Ease of getting information & 4.027 & 3.920 \\
\hline 23 & Ease of getting facilities & 3.993 & 3.847 \\
\hline 24 & No additional charges or payment (extortion) & 3.887 & 3.720 \\
\hline 25 & Arrival and departure time & 3.967 & 4.053 \\
\hline 26 & No longer for waiting time & 3.887 & 3.927 \\
\hline 27 & Ticketing service on time & 3.860 & 3.753 \\
\hline 28 & Durability of facilities services & 4.000 & 3.853 \\
\hline 29 & Durability of transportation services & 3.833 & 3.780 \\
\hline 30 & Normal queuing for passenger ticketing & 3.893 & 3.773 \\
\hline 31 & Passenger densities inside and outside of terminal & 3.973 & 3.880 \\
\hline 32 & No vehicle flow congestion occurs & 3.900 & 3.707 \\
\hline 33 & Free from cigarette smoke, vehicles smoke, and odors & 4.007 & 3.880 \\
\hline 34 & Free from noise, glare, and unfavorable view & 3.980 & 3.833 \\
\hline 35 & Cleanliness interior and exterior & 3.840 & 3.747 \\
\hline 36 & No ticket brokers & 4.040 & 3.547 \\
\hline 37 & Regularity in roads, parking, circulation, and space organization & 4.000 & 3.793 \\
\hline 38 & Availability of adequate parking space & 3.973 & 3.953 \\
\hline 39 & Availability of adequate waiting room space & 3.993 & 3.947 \\
\hline 40 & Availability of number of kiosk and retail facilities & 4.093 & 3.960 \\
\hline 41 & Availability of adequate waste facilities & 4.013 & 3.853 \\
\hline 42 & Availability of adequate lodging facilities & 3.740 & 3.667 \\
\hline 43 & Availability of canteen, restaurant, and food store & 3.973 & 3.807 \\
\hline 44 & Availability of travel information board & 3.860 & 3.713 \\
\hline 45 & Availability of information and complaint center & 3.960 & 3.940 \\
\hline 46 & Availability of safety goods repository & 3.880 & 3.920 \\
\hline 47 & Availability of adequate tariffs board and list per route & 4.133 & 3.880 \\
\hline 48 & Adequate on number of bathrooms and space for clean bathroom & 4.013 & 4.093 \\
\hline 49 & Clean religious facilities : place for pray & 4.053 & 3.840 \\
\hline 50 & There are transportation routes signs & 3.893 & 3.667 \\
\hline 51 & Availability of telecommunication facilities (telephone, internet, TV) & 4.013 & 3.907 \\
\hline 52 & Availability of travel agent counters & 4.027 & 3.860 \\
\hline 53 & Availability of health aid centre & 3.813 & 3.653 \\
\hline 54 & Availability of bank facilities, ATM center, and money changer & 3.520 & 3.433 \\
\hline
\end{tabular}




\section{Results of Validity and Reliability Test}

Before conducting IPA steps, the questionnaire as a data collecting tool must be measured levels of validity and reliability. Validity and reliability tests conducted on 30 respondents. Validity test conducted showed that all item questions for importance instrument has a correlation value greater than 0.6. While alpha coefficient of 0.934 and the value of alpha (Cronbach's Alpha) is greater than 0.6, meaning all items in question stated interest rate instruments valid and reliable. Results of validity and reliability of the instrument User Satisfaction of the 30 people showed that all item questions for User Satisfaction instruments have correlation values greater than 0.6. While alpha coefficient (Cronbach's Alpha) of 0.936 (is greater than 0.6). Thus, it means the item in question contains user satisfaction instruments are valid and reliable.

\section{Results of Continuation Survey}

Continuation survey conducted with a target of 150 respondents consisting of 75 public transport passengers who regularly (often) and rarely use the terminal. From Table 8 it can be seen the difference between the level of user satisfaction and importance to service attributes. The two aspects score is through importance-performance analysis (IPA). For more details, there is a comparison between user satisfaction and importance. The comparison will be explained in importance classification diagram (see Figure 3).

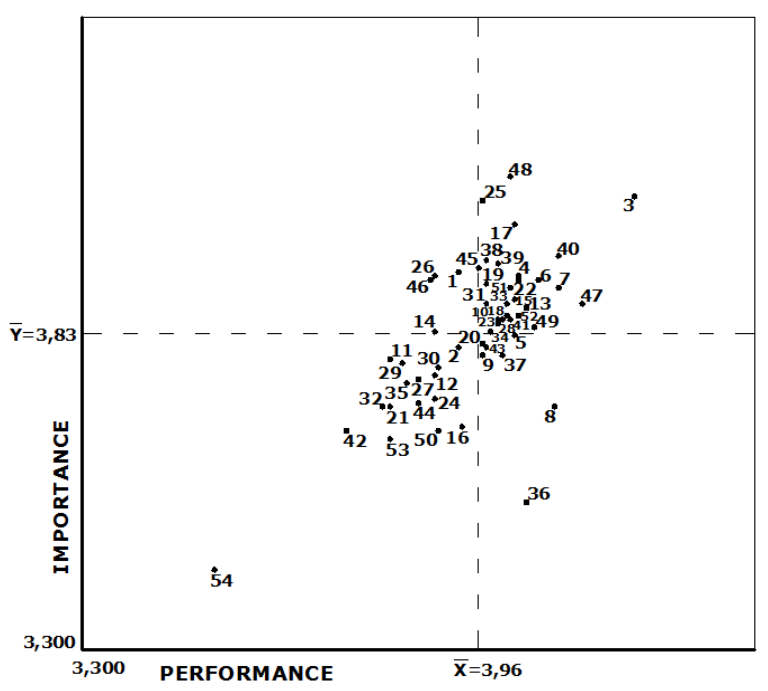

Figure 3. Importance Classification Diagram in Arjosari Terminal
Table 9. Priority Status of Service Attributes in Arjosari Terminal

\begin{tabular}{ll}
\hline \multicolumn{1}{c}{ Quadrant } & \multicolumn{1}{c}{ Service Attributes Number } \\
\hline A : High Priority & $1 ; 14 ; 26 ; 45 ; 46$ \\
B : Good & $3 ; 4 ; 6 ; 7 ; 10 ; 13 ; 15 ; 17 ; 18 ; 19 ; 22 ;$ \\
& $23 ; 25 ; 28 ; 31 ; 33 ; 34 ; 38 ; 39 ; 40 ; 41 ;$ \\
& $47 ; 48 ; 49 ; 51 ; 52$ \\
C : Low priority & $2 ; 11 ; 12 ; 16 ; 21 ; 24 ; 27 ; 29 ; 30 ; 32 ;$ \\
& $35 ; 44 ; 50 ; 53 ; 54$ \\
D : Excessive & $5 ; 8 ; 9 ; 20 ; 36 ; 37 ; 43$ \\
\hline
\end{tabular}

The results in Table 9 on the importance diagram (Figure 3 ) show that the mean value of importance $(\bar{Y})=3.83$ and satisfaction $(\bar{X})=3.96$. From these results it is shown that the main priority for repairs and improve by the terminal management institution include security and safety protection (no.1), aesthetic waiting room (14), no longer for waiting time (no.26), Availability of information and complaint center (no.45), and Availability of safety goods repository (no.46). While the service attributes are considered excessive consist Employees attention to all customer complaints (no.5), Employees have sufficient skills and abilities (no.8), Functioning of lighting (natural and artificial) (no.9), Easy for getting ticket (no.20), No ticket brokers (no.36), Regularity in roads, parking, circulation, and space organization (no.37), and Availability of canteen, restaurant, and food store (no.43).

\section{CONCLUSION}

Public transportation services are determined in part by which service attributes are prioritized based on the characteristics and needs of its users. The Factors influence Arjosari terminal services in order of user importance and satisfaction. The user is passengers who frequently and rarely use the terminal. Preliminary survey to obtain the 10 service attributes Assurance, Responsiveness, Performance, Aesthetics, Ease, Reliability, Durability, Frequency, Comfort, and the availability of facilities. The 10 attributes derived from availability of terminal facility that has the highest score according to the needs of users and facilities that are needed to be improved is the waiting room facilities. In the advanced stages of the survey received 54 service attributes and details using IPA analysis obtained security protection and safety attributes to be a very high priority for development. Subsequent research suggested that indepth analysis method to determine the priority and target of increasing public transport terminal services. 


\section{REFERENCES}

Anonymous (1995). Transportation Ministry Decision number 31/1995 about Transport Terminal. Jakarta-Indonesia: Ministry of Transportation, 3.

Anonymous (2009). Transport Terminal Analysis (a case study in DTA Downtown). LHB Inc. and LSA Design, Inc. 1-31.

Chen, C.H. (2009). A Quality Improvement Framework for Air Transport: An Example of Cargo Sector in Taiwan Taoyuan International Airport. National Science Council of Taiwan, 2-18.

Dragu, V. et al. (2001). Service Quality in the Terminal Joining Magistral and Urban Transport. Transportation Faculty, Politehnica University of Bucharest, Romania, 1-7.

Harsanto, B. (2007). Application of Quality Function Deployment in Railway Argo Wilis. Journal of Business and Management, 8(1), 1-12.

Ismail, S. (2008). Evaluation of Passengers Terminal (A case study in Pekanbaru Indonesia). Journal of Research and Riau, 8(4), 100-107.

Jarsemskiene, I. (2009). Research In The methods of Analyze the Productivity Indicators of Transport Terminals. Journal of Transport Research Institute, Lithuania Vilnius Gediminas Technical University, 1-9.

Kido, E.M. (2005). Aesthetic Aspects of Railway Station in Japan and Europe, as a part of "Context Sensitive Design for Railways". Transport Studies Tokyo-Japan, Journal of Eastern Asia Society, 6, 4381-4396.

Lutfi, Q. (2009). Factors in terminal displacement of Sidangoli to Sofifi North Maluku. Journal of Symposium XII FSTPT Petra Christian University, 174-184.

Marliana, S. and Dharmastiti, R. (2008). SERVQUAL and QFD Improving Integration Quality Transport Services Mass Trans Jogja. Proceedings of the National Seminar on Science and Technology Applications AKPRIND IST London, 110-114.

Nurfanti, Y. (2009). Factors Considered Quality Customer Service (Studies in Public Transportation Taxis in Malang). Post graduate of Economics and Bussiness, University of Brawijaya Malang.

Ockwell, A. (2001). Benchmarking Performance of Intermodal Transport. OECD Division of Australian Transport.
Pati, R. et al. (2009). Passenger Perceptions on the Service Quality of Travel Routes of Muara Teweh, Banjarmasin city. Journal of FSTPT, Petra Christian University, 1621-1633.

Purba, D. (2009). Priority Analysis of Influencing Factors to Effectiveness of Sarantama Terminal. Posgraduate of North Sumatra University, Medan-Indonesia, 80.

Rauf, N. (2002). Application of Quality Function Deployment in Improving Quality Public Transport Terminal Services: A Case Study In Public Transport Terminal Sungguminasa Gowa - Indonesia. Postgraduate of Industrial Engineering of the Tenth of November Institute of Technology, Surabaya - Indonesia, 1-3.

Rini, I.N.P. (2007). Analysis of Passenger Perceptions on the Level Services Bus Way (Case Study Trans Jakarta Bus Way Corridor I). Post graduate of Civil engineering, University of Diponegoro-Semarang.

Saputra, M. et al. (2010). User Satisfaction Analysis on Service Performance of Metro Makassar Terminal. Postgraduate of Civil Engineering of the Tenth of November Institute of Technology, Surabaya - Indonesia, 1-11.

Sholichin, I. et al. (2005). Analysis of Capacity and Level of Service In Bojonegoro Rajekwesi Terminal. National Seminar on Planning and Engineering $V$ Postgraduate of Veteran National Development University, Surabaya-Indonesia, 1-10.

Spekkink, D. (2005). Performance Based Design of Buildings, Final Report Domain, CIBdf, Netherlands, $18-20$.

Sugiyono (2009). Statistics for Research. Bandung: Alfabeta Publisher, 21-22.

Sulistio, H. and Silitonga, S.P. (2010). Scenario of Modal Split and Public Transport Utility in Palangkaraya, Malang, and Surabaya Cities of Indonesia. Journal of Mathematics and Technology Azerbaijan, 101-104.

Weningtyas, W. et al. (2009). Evaluation of a Minimum Service Standards (MSS) for Toll Road Infrastructure. Journal of FSTPT, Petra Christian University, 6.

Wijaya, T. (2011). Services Management Quality: SERVQUAL Design, QFD and Kano with Application in Research Cases. Index, JakartaIndonesia, 13-14. 